\title{
An Update on Breast Cancer Screening and Prevention.
}

\author{
Maria Syl D. de la Cruz \\ Thomas Jefferson University \\ Mona Sarfaty \\ Thomas Jefferson University \\ Richard C Wender \\ American Cancer Society
}

Follow this and additional works at: https://jdc.jefferson.edu/fmfp

Part of the Family Medicine Commons, and the Oncology Commons

Let us know how access to this document benefits you

\section{Recommended Citation}

de la Cruz, Maria Syl D.; Sarfaty, Mona; and Wender, Richard C, "An Update on Breast Cancer Screening and Prevention." (2014). Department of Family \& Community Medicine Faculty Papers. Paper 41.

https://jdc.jefferson.edu/fmfp/41

This Article is brought to you for free and open access by the Jefferson Digital Commons. The Jefferson Digital Commons is a service of Thomas Jefferson University's Center for Teaching and Learning (CTL). The Commons is a showcase for Jefferson books and journals, peer-reviewed scholarly publications, unique historical collections from the University archives, and teaching tools. The Jefferson Digital Commons allows researchers and interested readers anywhere in the world to learn about and keep up to date with Jefferson scholarship. This article has been accepted for inclusion in Department of Family \& Community Medicine Faculty Papers by an authorized administrator of the Jefferson Digital Commons. For more information, please contact: JeffersonDigitalCommons@jefferson.edu. 


\section{Title}

An Update on Breast Cancer Screening and Prevention

\section{Authors}

Maria Syl D. de la Cruz, MD

Mona Sarfaty, MD, MPH

Richard C. Wender, MD ${ }^{a, b}$

a Department of Family and Community Medicine, Thomas Jefferson University, Philadelphia, PA, USA

b American Cancer Society, Chief Cancer Control Officer, Atlanta, GA, USA

Corresponding Author:

Maria Syl D. de la Cruz, MD

833 Chestnut St, Suite 301

Philadelphia, PA 19107

215.503.3461 (office)

$215.955 .8600($ fax $)$

MariaSyl.delaCruz@jefferson.edu

Co-authors:

Mona Sarfaty, MD, MPH

4400 University Drive, 3D6

Fairfax, VA 2203

703.993.2086 (office)

msarfaty@gmu.edu

Richard C. Wender, MD

250 Williams St. 
Atlanta, GA 30303

404.329.4313 (office)

Richard.Wender@cancer.org

\section{Conflict of Interest}

Dr. de la Cruz: none

Dr. Sarfaty: none

Dr. Wender: none

\section{Acknowledgements}

The authors would like to thank Amy Burzinski for her assistance with the preparation of this manuscript. 


\section{Keywords}

breast cancer risk assessment, breast cancer screening, breast cancer prevention, mammography, breast MRI, guidelines

\section{Outline}

- Introduction

- Risk assessment for breast cancer

- Breast cancer prevention

- Breast cancer screening for women at average risk

- Breast cancer screening for women at high risk

- Current practice patterns

- Barriers to delivery

- Impact of changes on health care

- Summary/conclusion

\section{Abbreviations}

- ACS: American Cancer Society

- ACOG: American College of Obstetricians and Gynecologists

- BSE: Breast self-examination

- $\mathrm{CBE}$ : Clinical breast examination

- CTFPHC: Canadian Task Force on Preventive Health Care

- EHR: Electronic health record

- LCIS: Lobular carcinoma in situ

- MRI: Magnetic Resonance Imaging

- $\mathrm{NCCN}^{\circledR}$ : National Comprehensive Cancer Network ${ }^{\circledR}$

- PCMH: Patient-centered medical home

- SERM: Selective Estrogen Receptor Modulator

- USPSTF: United States Preventative Services Task Force 


\section{Synopsis}

The goal of this manuscript is to provide clinical guidance on breast cancer screening and prevention in primary care. The discussion highlights the importance of risk assessment, including screening options and risk reduction strategies for women at average and high risk. We review recommendations for breast cancer screening, evaluate current evidence on primary prevention, examine current practice patterns, and consider the impact of recent changes within health care.

\section{Key Points for Breast Cancer Screening and Prevention}

- Risk assessment is a key component for determining an individual's options for breast cancer screening and prevention.

- A primary care clinician needs to be able to identify risk factors that place a woman at higher than average risk for breast cancer, and if needed, place the appropriate referral for genetic counseling and risk reduction assessment.

- Mammography is universally recommended for women ages 50 to 74 , with the frequency of screening (annually or biennially) to be determined by individual patient preferences and a balance of net harms and benefits.

- While guidelines generally recommend offering screening for women ages 40 to 49 , some place additional emphasis on a shared decision making model between patient and providers.

- Preventive measures such as physical activity, tobacco cessation, limiting alcohol use, and maintaining a healthy weight should be encouraged for all women to reduce breast cancer risk, and chemoprevention with selective estrogen receptor modulators is an important consideration for women at high risk from breast cancer.

\section{Introduction}

Breast cancer-the most common noncutaneous cancer among women in the United States—kills more women every year than nearly all other cancers, falling only second to lung cancer.(1, 2) Surveillance estimates suggest over 230000 women will be diagnosed with breast cancer in 2014, and the disease will claim an estimated 40000 lives.(3) 
In the 1980 s and 1990s, the incidence of diagnosed breast cancer rose due to an increase in mammography screening. The incidence then decreased sharply from 2002 to 2003, largely attributable to a reduction in the use of hormone replacement therapy following findings from the Women's Health Initiative.(4) Since 2003, the incidence of diagnosed breast cancer has remained relatively stable.(1) Mortality rates from breast cancer have declined steadily since 1990. Among women younger than 50 , death rates have decreased on average by $3.2 \%$ per year; the rate of decline has been slightly lower in women older than 50 , at approximately $2.0 \%$ per year.(5) Continued improvements in cancer detection and treatment are the primary reasons for this drop;(6) however, not all segments of the population have benefited equally. Mortality rates, for example, have declined more slowly among blacks than whites, despite blacks' lower incidence rate. Age-adjusted mortality based on 2006-2010 surveillance data show the breast cancer incidence rate was 121.4 cases per 100,000 black females vs 127.4 cases per 100000 white females; mortality, however, was 30.8 deaths per 100000 black females vs 22.1 deaths per 100000 white females.(5) The five-year (2003-2009) relative survival rate is also lower for black females vs white females, at $78.7 \%$ vs $90.4 \%$, respectively.(5) This disparity has been attributed to multiple factors, including more aggressive tumors, social conditions, access to high quality health care, differences in detection (including screening behaviors), health system factors, and treatment differences.(7-12)

\section{Risk Assessment for Breast Cancer}

Risk factor assessment is critically important for breast cancer screening. Women should be divided into high risk or average risk categories to guide screening options and risk reduction strategies. While screening programs traditionally use age as the primary risk factor, the individual's collective risk factors determine the net benefits and harms of additional screening, such as genetic testing, or interventions to reduce risk, such as chemoprevention.

\section{Risk Factors}

Age. The most important risk factor for breast cancer is age. Approximately $10 \%$ of women are diagnosed between ages 35 and 44, 22\% are diagnosed between ages 45 and 54, and $25 \%$ are diagnosed between ages 55 and 64. Median age for diagnosis is 61 years, while the median age at death 
is 68 years. $(5)$

Family history and heritable gene mutations. Family history of breast or ovarian cancers on either the maternal or paternal side are also important risk factors, particularly in women diagnosed younger than 45 years of age.(13) Women who have one first-degree female relative with breast cancer have a 1.8 times higher risk of developing breast cancer compared to women with no family history. Having two first-degree relatives with breast or ovarian cancer increases breast cancer risk by almost 3fold; for women with three or more relatives, risk jumps by almost 4 -fold.(14) An estimated $10 \%$ of breast cancers can be attributed to an inherited gene mutation. $B R C A 1$ and $B R C A 2$ gene mutations are involved in hereditary breast and ovarian cancers, which occur with higher frequency in certain ethnic groups such as the Ashkenazi Jewish population. Other more rare mutations include TP53 and PTEN, which are associated with Li-Fraumeni syndrome and Cowden syndrome, both of which lead to an increased risk for breast cancer. The mutation in the $C D H 1$ gene involved with hereditary diffuse gastric cancer also predisposes women to an increased risk for lobular breast cancer.(13)

Clinical factors. Clinical factors that increase the risk of breast cancer include a history of proliferative lesions with atypia, history of chest irradiation, and breast density. Atypical ductal hyperplasia and atypical lobular hyperplasia increase risk by about 4 to 5 times compared to the average woman.(15) Risk is approximately doubled to 8 to 10 times for women with lobular carcinoma in situ (LCIS).(16) Women who received high-dose chest radiation at a younger age ( $\leq 30$ years), such as for Hodgkin lymphoma, have higher incidence rates starting about 8 years after radiation treatment.(17) High breast tissue density, a measure of the amount of glandular tissue relative to fatty tissue in the breast, has been shown to be a strong risk factor for the development of breast cancer.(18) Women with high breast tissue density have a 4 to 6 times increased risk of breast cancer compared to women with less dense breast tissue.(19-21) High density breast tissue also makes the detection of breast cancer by mammography more difficult.(20)

Reproductive factors._Factors that involve prolonged hormonal exposure may increase the risk for developing breast cancer, including early menarche, low parity, older age at first live birth, late menopause, and hormone replacement therapy (estrogen plus progestins). Conversely, factors that may be associated with decreased hormonal exposure, such as premature menopause (before age 40), may 
decrease the risk for developing breast cancer.(22) Other factors that may confer a protective effect include a younger age at first full-term pregnancy ( $<30$ years), a higher number of pregnancies,(23) and breastfeeding, particularly for more than one year.(24) A summary of the important risk factors for breast cancer is listed in Table 1.

\section{Risk Factor Tools}

The National Cancer Institute developed a tool based on the Gail model to estimate a woman's 5year risk and lifetime risk of invasive breast cancer.(25) This instrument-the Breast Cancer Risk Assessment Too-_includes reproductive risk factors (age of menarche, parity, age at first birth, breastfeeding, age at menopause), first-degree relatives with breast cancer, previous breast biopsies with or without atypical hyperplasia, and race. It is accessible online for free at http://cancer.gov/bcrisktool/default.aspx. However, the model cannot be applied to women who are younger than 35 years old or who have LCIS, ductal carcinoma in situ, or invasive cancer. It is also not appropriate for women with a strong family history of breast cancer, as it does not include maternal second- or third-degree relatives with breast cancer, paternal family history, male breast cancer, or ovarian cancer.(26) For women with a strong family history of breast or ovarian cancer, other statistical models should be utilized (BRCAPRO, ${ }^{a}$ BOADICEA, ${ }^{b}$ Claus).(27) For more information about the various instruments go to the following National Cancer Institute webpage: http://www.cancer.gov/cancertopics/pdg/genetics/breast-and-ovarian/HealthProfessional/page1. If the lifetime risk for an individual woman is $\geq 20 \%$, then increased surveillance with different imaging studies and risk reduction options should be reviewed with a health care professional.(13)

The primary care clinician. The primary care clinician's role involves identifying women who have a greater than average lifetime risk of developing breast cancer and designing a screening and risk reduction strategy in concert with the patient. The identification of women who meet criteria to consider genetic testing and their referral to a genetic counselor constitutes a clear primary care responsibility. The referral criteria for genetic testing for hereditary breast and ovarian cancer syndrome and further genetic risk assessment is reviewed in List 1 and Table 2. Additional online resources on how to order genetic testing and how to find a genetic counselor are available in Box 1.

\footnotetext{
${ }^{\mathrm{a}}$ http://bcb.dfci.harvard.edu/bayesmendel/brcapro.php
} 


\section{Breast Cancer Prevention}

A summary of recommendations for the primary prevention of breast cancer is outlined in List 2.

\section{Obesity, Physical Activity, Dietary Content}

Obesity is a risk factor for postmenopausal breast cancer, as a higher amount of fat tissue increases estrogen levels and subsequent risk. Weight gain specifically has been associated with an increased risk for breast cancer.(28) In a prospective cohort of over 80000 women, those who gained 55 pounds or more after age 18 years had an almost $50 \%$ higher risk of breast cancer. After menopause, women who gained 22 pounds or more had an $18 \%$ higher risk.(29) Data on weight loss in relation to breast cancer risk is less clear. The Nurses' Health Study showed women with a sustained weight loss of $\geq 22$ pounds since menopause and who had never used postmenopausal hormone replacement therapy had a lower breast cancer risk than women who simply maintained their weight.(29) However, another prospective cohort study in postmenopausal women found no association between a median weight loss of 11 pounds and a reduction in breast cancer, though this weight loss was not sustained in all women during the 5 year follow-up.(30) Studies in women who have undergone bariatric surgery suggest that surgical weight loss may be associated with a decreased risk of breast cancer.(31)(32) Using simulation modeling data, about $5.5 \%$ of breast cancer cases expected to occur in the year 2025 will be attributable to obesity. By 2025, the authors estimated there would be about 3300 to 5700 fewer breast cancer deaths in women age $\geq 25$ years if obesity was eradicated.(33)

There is growing evidence of a decreased risk of breast cancer with increased physical activity, particularly for postmenopausal women and women with hormone receptor negative tumors. $(34,35)$ The European Prospective Investigation into Cancer and Nutrition-a large prospective cohort study including over 250000 women—found an inverse association between breast cancer risk and moderate to high levels of total physical activity compared to those lowest in physical activity. For women diagnosed after age 50 years, the largest risk reduction was associated with the highest amount of physical activity; for women diagnosed before age 50 years, the largest risk reduction was associated with moderate total physical activity. Both estrogen-receptor-positive and progesterone-receptor-positive cancers were

\footnotetext{
${ }^{\mathrm{b}}$ http://ccge.medschl.cam.ac.uk/boadicea/
} 
inversely associated with moderate and high physical activity, suggesting that increased activity may lower concentrations of hormones and their related effect on estrogen sensitive tumors. Other mechanisms through which physical activity may mitigate risk include reduced chronic inflammation, increased antioxidant enzymes, and an improved immune system.(36)

The data linking dietary factors to breast cancer risk remains inconclusive and inconsistent. Three large reviews including prospective studies did not show a strong association between dietary factors (fruit and vegetables, total fat intake, fat biomarkers, vitamins [A, C, E, and beta-carotene], antioxidants, carbohydrates, dairy, soy) and risk for breast cancer.(37-39) A recent prospective study specifically looked at the role of total dietary fiber and its main food sources (vegetables, fruit, cereals, and legumes) with relation to breast cancer risk. After a median follow-up of 11.5 years, they found that a high dietary intake of total fiber and a high intake of fiber from vegetables were both associated with a decreased breast cancer risk, but not fiber from fruit, cereals, or legumes. The association between fiber and breast cancer risk was not modified by body mass index, waist-hip ratio, or alcohol consumption. The role of dietary fiber still remains unclear in breast cancer risk, and further studies are needed to elucidate the relationship between dietary content and breast cancer prevention.(40)

\section{Tobacco}

Studies have shown a strong association between current and previous tobacco use and risk of breast cancer. In a prospective cohort study of almost 80000 women, current smokers had a $16 \%$ higher risk of breast cancer and former smokers had a $9 \%$ increased risk over non-smokers. This increased breast cancer risk remained up to 20 years after smoking cessation. For nonsmokers, a very high exposure to passive smoking (defined as $\geq 10$ years' exposure in childhood, $\geq 20$ years' exposure as an adult at home, and $\geq 10$ years' exposure as an adult at work) resulted in a $32 \%$ increased risk of breast cancer compared with those never exposed to secondhand smoke.(41) Another study including nearly 3000 women found a significant increased risk of all-cause mortality in women who smoked either 15-24 cigarettes or $25+$ cigarettes per day, with the highest risk for women who smoked the highest quantity. Overall, women who smoked for $20+$ pack-years had a $54 \%$ increase in breast cancer mortality and an $81 \%$ increase in all-cause mortality.(42)

\section{Alcohol}


Alcohol use has been found to be associated with an increased risk of breast cancer in a number of studies.(43-45) Women who consumed 3 to 14 drinks per week had a $12 \%$ increased risk of breast cancer for every drink (10 $\mathrm{g}$ of alcohol) consumed per day(46); this dose-dependent risk is independent of the specific type of alcoholic beverage. $(43,45,46)$ The mechanism linking alcohol consumption to increased breast cancer risk may be alcohol's capacity to raise circulating concentrations of sex hormones.(46-48) Evidence does not support an association between alcohol intake and increased breast cancer risk among women who were past users or are current users of hormone replacement therapy when compared to those never using the therapy.(46, 49-51)

\section{Chemoprevention for Patients at High Risk: Selective Estrogen Receptor Modulators (SERMS)}

Randomized trials have shown that chemoprevention with drugs like tamoxifen and raloxifene reduce breast cancer risk. In 1998, the first randomized trial with over 13000 women demonstrated that tamoxifen could reduce the risk of breast cancer in high-risk women with estrogen receptor positive tumors.(52) Breast cancer risk was decreased by $42 \%$ in the tamoxifen group after an average of 7 years of follow up compared to the control group. This protective effect continued for up to 10 years after completion of the 5-year treatment. Although tamoxifen was associated with a lower risk of breast cancer, the net benefit was reduced as a result of an increase in the risks of endometrial cancer, stroke, venous thromboembolism, cataracts, and vasomotor symptoms. However, tamoxifen also demonstrated the potential benefit of fracture reduction, particularly in postmenopausal women. $(53,54)$ Despite this decrease in breast cancer risk, no trials with tamoxifen have shown an effect on all-cause mortality or breast cancer-specific mortality.(55-58)

Raloxifene, a drug originally studied for osteoporosis prevention, was also observed to decrease the risk of breast cancer.(59) In the Study of Tamoxifen and Raloxifene trial, raloxifene was nearly as effective as tamoxifen in preventing invasive breast cancer and had a lower risk of side effects. As observed with tamoxifen, this risk reduction effect applies only to the development of estrogen receptor positive breast cancer. No difference was found in the number of deaths between tamoxifen and raloxifene.(60) Other trials have also failed to show a mortality benefit for raloxifene, but notably, they lacked sufficient power to detect significant differences in mortality over their course of follow-up. $(61,62)$ An updated meta-analysis of over 80000 women found that 4 SERMS (tamoxifen, raloxifene, 
arzoxifene, and lasofoxifene) reduced breast cancer by $38 \%$ compared to the control group. An increased rate of endometrial cancer was mostly limited to the tamoxifen trials. Risk for venous thromboembolism was similar between tamoxifene and raloxifene, with a slightly increased rate with arzoxifene and lasofoxifene. All SERMS had similar risk reduction for fractures, and no effect of SERMs was found for myocardial infarction, stroke, or transient ischemic attacks.(54)

Due to risk of adverse effects, SERMS are recommended only for women at high risk for breast cancer. The National Comprehensive Cancer Network ${ }^{\circledR}$ Clinical Practice Guidelines In Oncology (NCCN Guidelines $^{\circledR}$ ) for Breast Cancer Risk Reduction recommend tamoxifen as an option in women 35 years or older, with a life expectancy $\geq 10$ years, who have had LCIS, or have a $\geq 1.7 \% 5$-year risk for breast cancer by the modified Gail model.(63) Tamoxifen is the more favorable choice of a risk reduction agent compared to raloxifene for most postmenopausal women, based on results that showed less continued benefit of raloxifene compared to tamoxifen after cessation. $(60,63)$

\section{Breast Cancer Screening for Women at Average Risk}

A summary of recommendations for breast cancer screening in average-risk women is listed in Table 3.

\section{Mammography}

Ages 40-49 years. Multiple studies have evaluated the benefits and harms of screening in women age 40 years and older, but few have specifically evaluated the age group of women aged 40 to 49. The Age Trial looked specifically at women between the ages of 39 and 41 years, who were randomized to participate in annual mammography until age 48 . The reduction in breast cancer mortality in the test group was not statistically significant after 10.7 years of follow up; however, adjusting for noncompliance in women actually screened showed an estimated $24 \%$ reduction in mortality risk. Moreover, a meta-analysis of 8 trials (including the Age Trial) showed a 16\% reduced risk in breast cancer mortality.(64) Some of this benefit is likely attributable to the inclusion of women up to age 49 years at entry in all studies except the Age Trial.(50) In a re-analysis of the Gothenburg trial looking at women aged 39 to 49 years, screening mammography was found to reduce risk by $31 \%$ for breast cancer mortality after 13 years of follow-up.(65) After combining data from 7 randomized trials- only 3 of which 
employed adequate randomization —an updated Cochrane review found a $19 \%$ risk reduction in breast cancer mortality after 7 years and a 20\% reduction after 13 years; however, when the three trials with adequate randomization were examined alone no statistically significant effect was detected(66)

Conducting its own systematic review, the United States Preventative Services Task Force (USPSTF) reported that mammography reduces breast cancer mortality by $15 \%$ for women aged $40-49$ years, with an overdiagnosis estimates varying between $1 \%$ and $10 \% .(67)$; these findings are similar to those reported by the Canadian Task Force on Preventive Health Care (CTFPHC).(68) Both the USPSTF and CTFPHC report an increased rate of false positives in women aged 40-49 years; hence, they both recommend that women ages 40 to 49 make an informed and shared decision whether or not to participate in mammography screening; neither group endorses routine screening of all women aged 4049 years in the absence of shared decision making. $(67,68)$ Other groups-notably, the American College of Obstetricians and Gynecologists (ACOG), the American Cancer Society (ACS), and the $\mathrm{NCCN}^{\circledR}$ continue to recommend routine screening in women 40 to 49 . These groups cite evidence that the mortality risk reduction associated with screening younger women is comparable to the benefit observed in screening older women(69-71). They also judged that the balance of benefits and harms favored a strategy of routine screening for all younger women. In addition, a large case control study published after release of the USPSTF and CTFPHC guidelines suggests a lack of screening in women aged 40 to 49 years is associated with a higher death rate from breast cancer. Among 609 confirmed breast cancer deaths, $71 \%$ occurred in women who were not screened regularly while $29 \%$ occurred in women who had been screened with mammography. In this study, the death rate from breast cancer was actually higher in women aged $<50$ years compared to women aged $\geq 50$ years. (72)

Ages 50-69 years. Screening mammography in women aged 50 to 69 years has been proven in multiple randomized trials to reduce breast cancer mortality from $15-20 \% .(65-68,73-79)$ Based on the higher incidence of breast cancer in this age group and the evidence of reduction on breast cancer mortality, cancer screening guidelines continue to recommend screening mammography. However, there is still debate over the frequency at which screenings should occur. The USPSTF commissioned screening models by 6 independent groups within the Cancer Intervention and Surveillance Modeling Network to identify the most efficient screening strategy. The investigators found that the method of 
starting screening at age 50 years and continuing biennially to age 69 years strikes the right balance between decreasing breast cancer mortality against potential harms.(80) However, some guideline groups continue to recommend offering annual screening, whereas others emphasize that the decision about screening frequency should be shared with the patient, based on their personal values.

Ages 70 years and over. Results from the Swedish Two-County trial of women aged 70 to 74 years showed no reduction in mortality with breast cancer screening.(77) However, the CTFPHC notes that the absolute benefits of mammography in women aged 70 to 74 years are likely comparable to those for women aged 50-69 years due to the higher absolute risk in older women. The CTFPHC therefore recommends routine mammography every two to three years in women aged 70 to 74 years as a weak recommendation based on low-quality evidence.(68) Similarly, the USPSTF continues to recommend biennial screening until age 74 for women who are in good health.(67) Overall, the decision to continue screening beyond the age of 75 years should take into account individual patient circumstances and preferences.

\section{Breast Ultrasound}

Breast ultrasound has been studied particularly for screening women with high breast density due to the lower sensitivity of mammography in these patients. One study found that $42 \%$ of all women with nonpalpable invasive breast cancer had their cancers detected only with screening ultrasound, and $37 \%$ of all cancers in women with dense breasts were detected only with screening ultrasound.(81) In another study of women with dense breast tissue who received either mammography plus ultrasound or mammography alone, supplemental ultrasound detected an additional 4.2 cancers per 1000 women.(82) While these studies show promising results for the use of ultrasound in women with high breast density, at this time there is no recommendation for performing ultrasound as part of routine breast cancer screening.

\section{Breast Self-Examination}

A few large trials have analyzed the effect of instructing women in breast self-examination (BSE) on reducing breast cancer mortality. The UK Trialists study, a nonrandomized study with 16 years of follow up, showed no significant difference in breast cancer mortality between the BSE and control groups.(83) A Cochrane review included randomized trials comparing BSE to control groups in both 
Russia(84) and Shanghai,(85) with each study showing no significant differences in breast cancer mortality after 13 and 11 years, respectively.(86) Furthermore, these trials show women performing BSE had an increased number of breast biopsies (53\%) and they were not more likely to be diagnosed with breast cancer compared to women who were not taught BSE after 5 years of follow-up.(87) Another study showed that women 40 and older who performed more frequent or longer BSE were more likely to have a diagnostic mammography or ultrasound.(88) Overall, these findings do not support regular BSE as an effective screening method for decreasing breast cancer mortality.

Although no screening organization now recommends routine instruction of women in BSE, several organizations making recommendations do promote the concept of breast self-awareness. The ACS, the $\mathrm{NCCN}^{\circledR}$, and ACOG all promote teaching patients about breast self-awareness, the concept that a woman should be familiar with her own breasts and bring any changes to the attention of her health provider. Women should still be encouraged to report new breast changes, but they are not advised to perform a specific self-examination technique.(69-71)

\section{Clinical Breast Examination}

The efficacy of the clinical breast examination (CBE) has been investigated in a few large trials. In community settings assessing CBE as part of the National Early Detection Program, CBE detected 5.1\% of breast cancers that were not detected by mammography and therefore could have been missed with mammography alone. The procedure for conducting a CBE was not reported, but the estimated sensitivity (ability of the test to correctly identify those patients with the disease (89)) for CBE was $58.8 \%$ and specificity (ability of the test to correctly identify those patients without the disease (89)) was 93.4\%,(90) similar to previous estimates. In a Canadian study of 300000 women aged 50 to 69 , CBE increased the rate of detection of small invasive cancers over mammography alone by a small amount, between $2 \%$ to $6 \%$. Trained nurses or physicians performed the CBE, which included visual inspection followed by a systematic 10-minute examination.(91) None of these trials showed a significant difference in breast cancer mortality between screening with combined mammography and CBE compared to mammography alone.(92)

The USPSTF found a lack of evidence to recommend for or against breast cancer screening with CBE apart from mammography.(93) The utility of CBE as a detection method, however, has relied on its 
performance characteristics. The variation of CBE techniques performed by clinicians makes it challenging to assess the efficacy of the clinical examination in routine practice, which may not meet the standards of the Canadian trial. Most professional guideline groups advocate incorporating CBE as long as it is performed correctly. Per the ACS recommendations, after visual inspection and palpation of lymph nodes, the examiner should use the pads of the middle three fingers using circular motions, to cover the area down the midaxillary line, across the inframammary ridge at the fifth/sixth rib, up the lateral edge of the sternum, across the clavicle, and back to the midaxilla. A vertical strip pattern is preferred over the concentric circle pattern, and the exam should palpate at increasing levels of pressure (superficial, intermediate, and deep).(94)

\section{Breast Cancer Screening for Women at High Risk}

The recommendations for screening and risk reduction for women at high risk from breast cancer are summarized in Table 4.

\section{Magnetic Resonance Imaging}

In April 2007, the ACS released guidelines on the use of annual breast magnetic resonance imaging (MRI) in addition to mammography for breast cancer screening in women at high risk. This includes women who have an approximate lifetime risk $\geq 20 \%$; namely, those who are $B R C A$ mutation carriers, first-degree relatives of known $B R C A$ mutation carriers who have not undergone genetic testing, women who received chest irradiation between 10 and 30 years ago, Li-Fraumeni syndrome and firstdegree relatives, Cowden and Bannayan-Riley-Ruvalcalba syndromes and their first-degree relatives. Insufficient evidence for screening with MRI exists for LCIS, atypical ductal hyperplasia, heterogeneously dense breasts, women with a personal history of breast cancer, or women with a lifetime risk <20\%.(95)

Although not exclusive to $B R C A 1$ and 2 carriers, MRI combined with mammography has a higher sensitivity compared to mammography alone (70\%-97\% and 23\%-41\%, respectively)(96); however, specificity is lower with the combined method (75\%-97\%) versus mammography alone (93\%-99\%) because of the high number of false positives with MRI(96). Although studies show that breast MRI screening of $B R C A 1$ and $B R C A 2$ mutation carriers detects breast cancer earlier and more frequently than mammography, none has demonstrated an improvement in mortality or survival, largely related to the 
difficulty in conducting adequately large clinical trials.(96-103)

$\mathrm{NCCN}^{\circledR}$ recommendations for women who are $B R C A 1 / B R C A 2$ mutation carriers includes breast awareness starting at age 18, a clinical breast exam every 6 to 12 months, annual mammogram and MRI starting at age 25 , a discussion of risk-reducing mastectomy and risk-reducing salpingo-oophorectomy, and consideration of chemoprevention.(13) For a more detailed discussion, see NCCN Guidelines ${ }^{\circledR}$ Genetic/Familial Risk Assessment for Breast Cancer.(13)

\section{Current Practice Patterns}

The release of the 2009 USPSTF recommendations instigated public debate among advocacy and specialty organizations regarding the changes to individualized consultation and decision making for screening mammography for the 40 to 49 age group. Initial studies have assessed changes to practice patterns since the new recommendation. The National Health Interview Survey asked 27, 829 women aged 40 and over to self-report mammography screening in the past year. Although there was a slight increase in the age-adjusted rates of self-reported mammography from 2008 to 2011, 2011 rates were not significantly different compared with 2008 for women in any age group.(104) Similarly, the Medical Expenditure Panel Surveys analyzed the biennial mammography rate for almost 30,000 women in 3 different age groups ( 40 to 49,50 to 74 , and 75 and older), and found no statistically significant difference in mammography rates between 2010 and earlier years (pooled rate 2006-2009) for any age group.(105)

Various studies have also evaluated screening preferences and differences based on specialty. In a web-based survey (106) of 11, 922 primary care physicians, over $95 \%$ recommended screening mammography to women aged 50-69 years, regardless of specialty. However, for women 40-49 years old, $94 \%$ of obstetrician gynecologists always recommended mammography compared to $81 \%$ of internal medicine physicians and $84 \%$ of family medicine physicians. Similarly, for women ages 70 and older, $86 \%$ of obstetrician gynecologists always recommended screening mammography compared to $67 \%$ for internal medicine and $59 \%$ for family medicine physicians.

Another survey (107) led by the National Cancer Institute asked 1212 primary care physicians about their breast cancer screening practices. The ACS guidelines were cited as the most influential (56\%), followed by ACOG (47\%), USPSTF (42\%), American Academy of Family Physicians (32\%), and 
American College of Physicians (25\%) guidelines. More than two-thirds of all physicians recommended mammography to women 40 to 49 annually compared to greater than $90 \%$ of all physicians who recommended annual mammography to women 50 years and over. Also, both family medicine and internal medicine physicians were more likely to no longer recommend screening at a certain age (30.2\% and $37.8 \%$, respectively) than obstetrician gynecologists (14\%).(109) Despite the varying recommendations, ultimately it is the responsibility of the provider to discuss the net harms and benefits of breast cancer screening with each patient to determine individual screening preferences.

\section{Barriers to Delivery}

Despite having access to health care, many women are not being screened.(108) National Medicare data demonstrate that only $64 \%$ of eligible woman (65 and older) have had a mammogram within the previous two years. Screening rates in Medicare-eligible women who have family incomes less than $100 \%$ of the federal poverty rate are even lower (51\%).(109) Furthermore, use of screening mammography varies by race and ethnicity. Hispanic, Asian, and foreign-born women who have lived in the United States for less than 10 years have lower rates of screening compared to other women.(108)

Several factors influence a woman's decision to obtain screening services. According to one systematic review, barriers that affect a woman's decision to obtain screening include concerns about mammography safety, pain associated with the procedure, language and cultural differences, provider biases, lack of social support, and lack of knowledge.(110) A report by the Institute of Medicine in 2003 revealed a major influencing factor was a woman's knowledge about the risk of breast cancer and the benefits of screening.(111) In a study of 20 focus groups with women from multiple racial and ethnic backgrounds (112), the major reasons for not getting a repeat mammogram included concerns about test efficacy, time needed to schedule appointments, competing family demands, and concern about radiation exposure. Regardless of age, some women did not think they were at high risk for breast cancer due to a negative family history. The most commonly cited barriers to breast cancer screening in a 2006 survey of primary care physicians (113) included a lack of patient follow through on mammography, lack of insurance coverage for screening, and lack of time to discuss screening. These barriers could be better addressed if providers were aware of the aforementioned patient concerns and the lack of education on 
screening.

Another challenge to breast cancer screening is ensuring appropriate follow-up of abnormal results. Minority women and those with poorer socioeconomic status are less likely to have timely followup after abnormal screening results and are more often diagnosed with late-stage disease. In a study of women with late-stage breast cancer at the time of diagnosis, $52 \%$ were not screened according to guidelines and $8 \%$ did not receive timely follow-up of their abnormal mammograms.(114) However, a wide variability in quality of care exists for cancer screening diagnosis and follow-up of abnormal tests, even among patients with insurance.(115)

Racial disparities in breast cancer include the discrepancy in mortality rates between blacks compared to whites. Cook County (Illinois, USA) investigators who analyzed 25, 900 cases of breast cancer found that black women were more likely to be diagnosed at later stages than white women at any age after evaluating by stage, geocode, race/ethnicity, and socioeconomic status. Hispanic women were also likely to have a later diagnosis than white women up until about age 68. Poverty was also a predictor of being diagnosed with breast cancer at a later stage.(116) In another study, black women had a statistically significant lower 5-year survival rate (55.9\%) compared to white women (68.8\%). After matching for presentation characteristics, white patients were more likely to receive treatment compared to black patients, mean time from diagnosis to treatment was longer for black patients, and black patients were less likely to receive treatment with chemotherapy and more likely to receive breast-conserving surgery without other treatment compared to white patients. These presentation characteristics accounted for the majority of the difference in the absolute survival rates between black and white women. Compared to white patients, black patients had a poorer state of health at time of diagnosis with a higher number of comorbidities, more advanced disease, and worse prognostic features (eg, estrogen receptor status).(117)

\section{Impact of Changes Within Health Care}

\section{Affordable Care Act}

A review including 195 research studies with 4.8 million United States women found that a lack of health insurance was a major predictor of women not obtaining mammography.(110) As the Affordable 
Care Act is fully implemented, the expansion of Medicaid along with subsidized state insurance exchanges and elimination of cost sharing is expected to improve access to breast cancer screening for many women. The United States Census Bureau's 2009 American Community Survey of adults aged 18 to 64 estimated that about 2.8 million low-income women aged 40 to 64 will gain health insurance as a result of the Affordable Care Act.(118) This translates into an additional 500000 women who will receive breast cancer screening in the first year of the act, and an estimated additional 1 million more over the subsequent 2 years.(116)

\section{Patient-Centered Medical Home and the Electronic Health Record}

The creation of a patient-centered medical home $(\mathrm{PCMH})$ focused on preventive health and care coordination will help deliver cost effective, efficient primary care. In order to accomplish this goal, $\mathrm{PCMH}$ approaches to care need to effectively identify women who are eligible to be screened, particularly targeting under-screened groups such as racial and ethnic minorities. Health assessment tools, detailing a complete family history, the clinical team, and electronic health record (EHR) systems can help to identify people who should be screened. The EHR can flag patients who are at high risk based on personal and family risk factors entered into the system by the clinical team. Outreach efforts can be conducted through electronic reminders, mail, or telephone to assist with scheduling and addressing screening concerns.(119) The collection of data on screening practices and breast cancer trends within the medical home can guide the delivery of preventive services, especially regarding current mammography utilization and geographic disparities. For example, women who live in rural areas of the US have a significantly lower rate of breast cancer screening compared to women living in urban areas.(120) Due to the limited time in an office visit, the use of multicultural and multilingual decision aids (video, online, and print education tools) can help address the barriers of health literacy and lack of knowledge about the benefits and risks of screening. Patient navigators, defined as those assigned to helping patients overcome barriers to care, can assist with patient education, language and cultural issues, scheduling appointments, transportation, or other logistical problems. The use of the EHR can also contribute to more effective cancer screening outreach efforts, such as identifying screening-eligible women and triggering follow-up of abnormal screening results. $(119,121)$ In a study investigating EHR use and quality measures, investigators found that breast cancer screening improved by nearly 4.5 
percentage points in sites using EHRs.(122)

\section{Summary/Conclusion}

Risk stratification in breast cancer prevention and screening is a key component to reduce breast cancer mortality. Preventive measures such as physical activity, tobacco cessation, limiting alcohol use, and maintaining a healthy weight should continue to be emphasized as part of a healthy lifestyle and to minimize breast cancer risk. Chemoprevention with selective estrogen receptor modulators is also an important consideration for women who are at high risk for developing breast cancer. Identifying women who have a greater than average lifetime risk of breast cancer and referring them for genetic testing or counseling is a significant responsibility of the primary care provider. Given the variable guideline recommendations, a shared decision making model will increasingly become an essential tool for primary care providers in counseling patients on cancer screening options. Primary care providers will need to incorporate patients' personal and family risk factors, individual preferences, and recommended guidelines to provide their patients with appropriate screening and risk reduction recommendations. While implementation of the Affordable Care Act provides an opportunity to increase screening rates, public health efforts should continue to develop a comprehensive and collaborative model to reduce health disparities in breast cancer screening, prevention, and treatment. 


\begin{tabular}{|c|c|}
\hline Relative Risk & Factor \\
\hline$>4.0$ & $\begin{array}{l}\text { - Age (65+ vs <65 years, although risk increases across } \\
\text { - } \text { all ages until age } 80) \\
\text { - Certain inherited genetic mutations for breast cancer } \\
\text { (BRCA1 and/or BRCA2) } \\
\text { - Lobular carcinoma in situ } \\
\text { - Mammographically dense breasts } \\
\text { - Personal history of early onset (<40 years) breast cancer } \\
\text { - Two or more first-degree relatives with breast cancer } \\
\text { diagnosed at an early age }\end{array}$ \\
\hline $2.1-4.0$ & $\begin{array}{l}\text { - Personal history of breast cancer (40+ years) } \\
\text { - High endogenous estrogen or testosterone levels } \\
\text { (postmenopausal) } \\
\text { - High dose radiation to chest } \\
\text { - One first-degree relative with breast cancer }\end{array}$ \\
\hline $1.1-2.0$ & $\begin{array}{l}\text { - Alcohol consumption } \\
\text { - Ashkenazi Jewish (Eastern European) heritage } \\
\text { - Diethylstilbesterol (DES) exposure } \\
\text { - Early menarche (age <12 years) } \\
\text { - Height (tall) } \\
\text { - High socioeconomic status } \\
\text { - Late age at first pregnancy (age >30 years) } \\
\text { - Late menopause (age >55 years) }\end{array}$ \\
\hline
\end{tabular}




\begin{tabular}{|l|l|}
\hline - Never breastfed a child \\
- No full-term pregnancies \\
- Obesity (postmenopausal)/adult weight gain \\
- Personal history of endometrium, ovary, or colon cancer \\
- Recent and long-term use of menopausal hormone \\
therapy containing estrogen and progestin \\
- Recent oral contraceptive use
\end{tabular}

Adapted from American Cancer Society. Breast Cancer Facts and Figures 2013-14. Atlanta (GA):

American Cancer Society, Inc. 2013. p. 12 


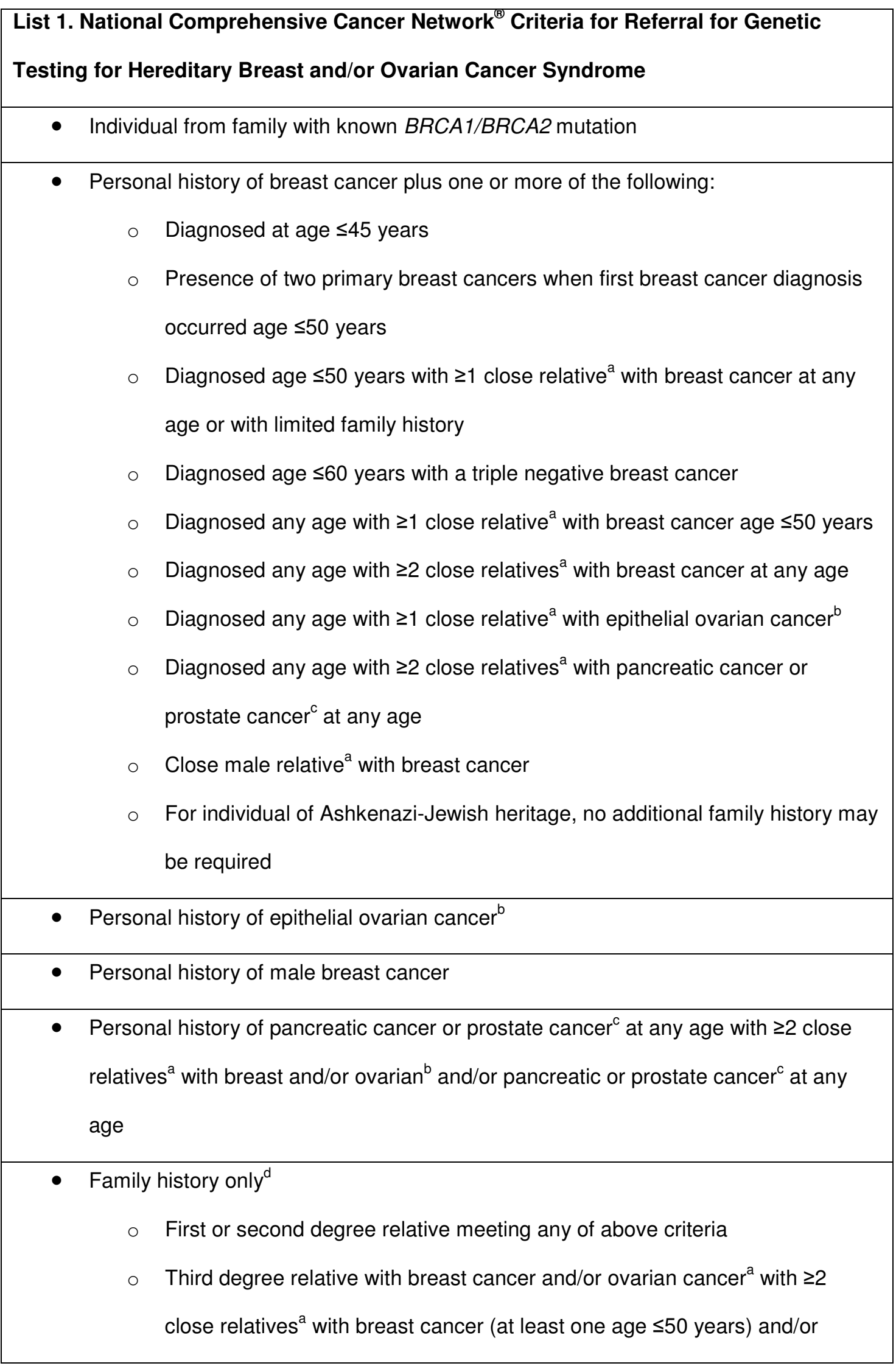




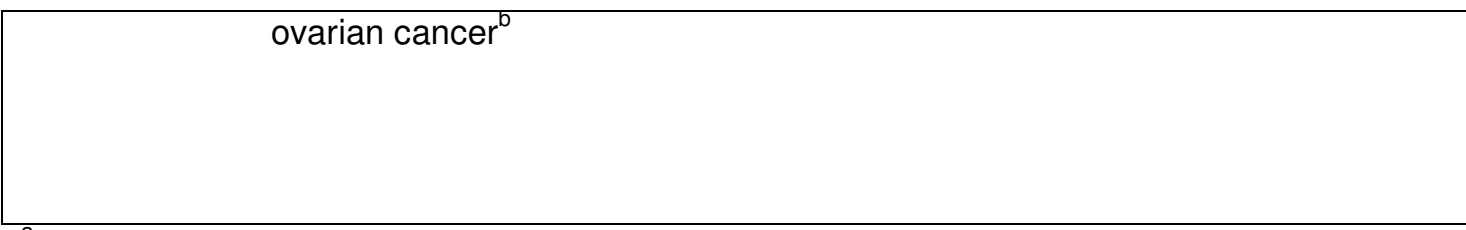

${ }^{a}$ First, second, or third-degree relative

${ }^{\mathrm{b}}$ Includes fallopian tube and primary peritoneal cancers

c Gleason score $\geq 7$

${ }^{d}$ Significant limitations of interpreting test results for an unaffected individual should be discussed.

Testing of unaffected individuals should only be considered when an appropriate affected family member is unavailable for testing. Clinical judgment should be used to determine if the patient has reasonable likelihood of a mutation, considering the unaffected patient's current age and the age of female unaffected relatives who link the patient with the affected relatives.

Adapted with permission from the NCCN Clinical Practice Guidelines in Oncology (NCCN Guidelines $®$ ) for Genetic/Familial Risk Assessment: Breast and Ovarian V.4.2013. ( 2013 National Comprehensive Cancer Network, Inc. All rights reserved. The NCCN Guidelines $\AA^{\circledR}$ and illustrations herein may not be reproduced in any form for any purpose without the express written permission of the NCCN. To view the most recent and complete version of the NCCN Guidelines, go online to NCCN.org. NATIONAL COMPREHENSIVE CANCER NETWORK®, NCCN®, NCCN GUIDELINES®, and all other NCCN Content are trademarks owned by the National Comprehensive Cancer Network, Inc. 


\begin{tabular}{|c|c|}
\hline $\begin{array}{l}\text { An affected individual with one or more of } \\
\text { the following: }\end{array}$ & $\begin{array}{l}\text { An unaffected individual with a family } \\
\text { history of one or more of the following: }\end{array}$ \\
\hline $\begin{array}{l}\text { - A known mutation in a breast cancer } \\
\text { susceptibility gene within the family }\end{array}$ & $\begin{array}{l}\text { - A known mutation in a breast cancer } \\
\text { susceptibility gene within the family }\end{array}$ \\
\hline - Early-age-onset breast cancer & $\begin{array}{l}\text { - } \quad \geq 2 \text { breast primaries in single } \\
\text { individual }\end{array}$ \\
\hline $\begin{array}{l}\text { - Triple negative (ER-/PR-/HER2-) } \\
\text { breast cancer }\end{array}$ & $\begin{array}{l}\text { - } \quad \geq 2 \text { individuals with breast primaries } \\
\text { on same side of family }\end{array}$ \\
\hline $\begin{array}{l}\text { - Two breast cancer primaries in a } \\
\text { single individual }\end{array}$ & $\begin{array}{l}-\quad \geq 1 \text { ovarian cancer }{ }^{b} \text { primary from the } \\
\text { same side of family }\end{array}$ \\
\hline $\begin{array}{l}\text { - Breast cancer at any age, and } \\
\circ \quad \geq 1 \text { close relative }{ }^{\mathrm{a}} \text { with breast } \\
\text { cancer age } \leq 50 \text { years, or } \\
\circ \quad \geq 1 \text { close relative }{ }^{\mathrm{a}} \text { with } \\
\text { epithelial ovarian cancer }{ }^{\mathrm{b}} \text { at } \\
\text { any age } \\
\quad \geq 2 \text { close relatives }{ }^{\mathrm{a}} \text { with breast } \\
\text { cancer and/or pancreatic } \\
\text { cancer at any age } \\
\text { From a population at } \\
\text { increased risk }\end{array}$ & $\begin{array}{l}\text { First or second degree relative with } \\
\text { breast cancer age } \leq 45 \text { years }\end{array}$ \\
\hline
\end{tabular}




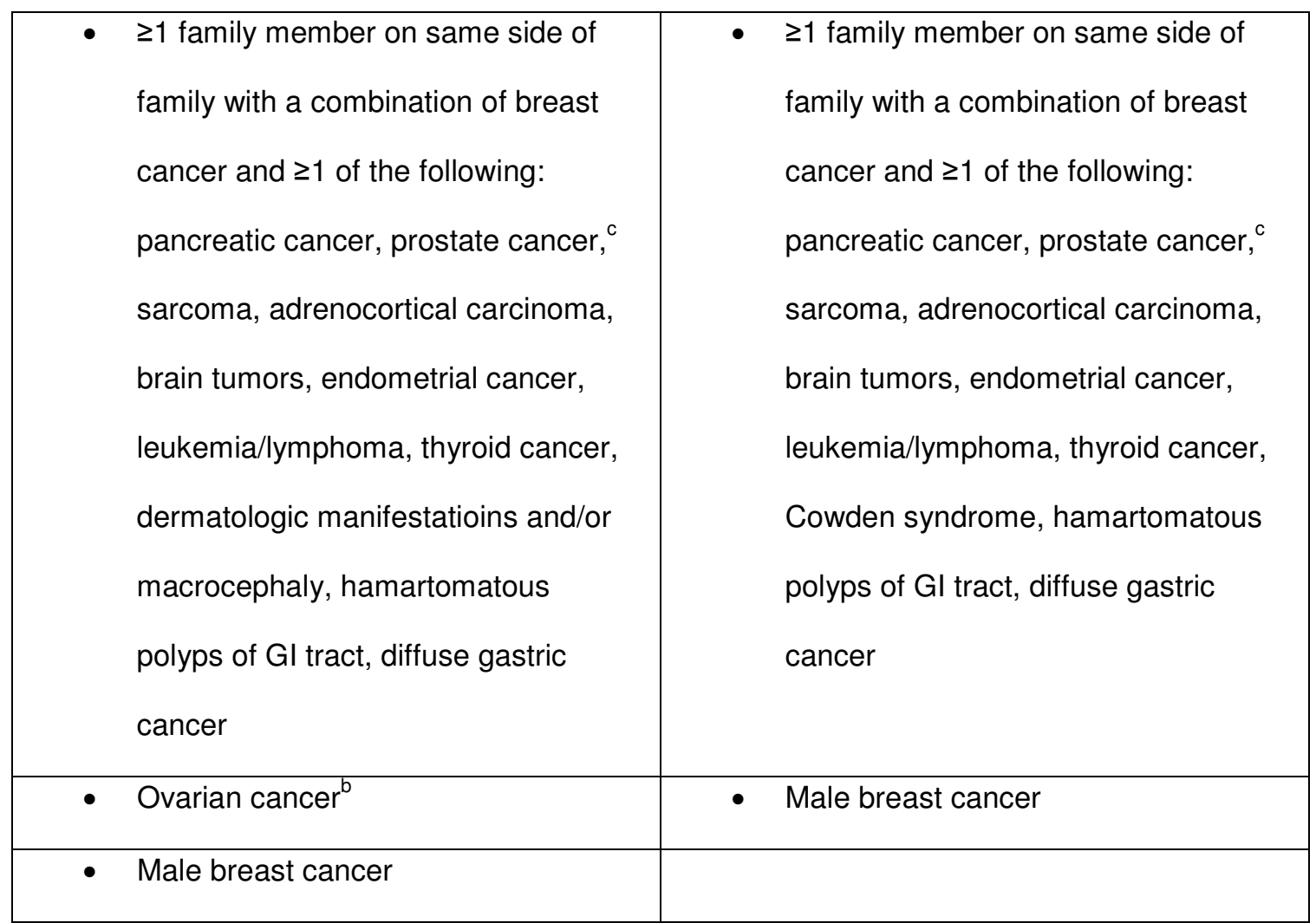

a First, second, or third-degree relative

b Includes fallopian tube and primary peritoneal cancers

c Gleason score $\geq 7$

Adapted with permission from the NCCN Clinical Practice Guidelines in Oncology (NCCN Guidelines ${ }^{\circledR}$ ) for Genetic/Familial Risk Assessment: Breast and Ovarian V.4.2013. @ 2013 National Comprehensive Cancer Network, Inc. All rights reserved. The NCCN Guidelines ${ }^{\circledR}$ and illustrations herein may not be reproduced in any form for any purpose without the express written permission of the NCCN. To view the most recent and complete version of the NCCN Guidelines, go online to NCCN.org. NATIONAL COMPREHENSIVE CANCER NETWORK®, NCCN®, NCCN GUIDELINES $\AA^{\circ}$, and all other NCCN Content are trademarks owned by the National Comprehensive Cancer Network, Inc. 


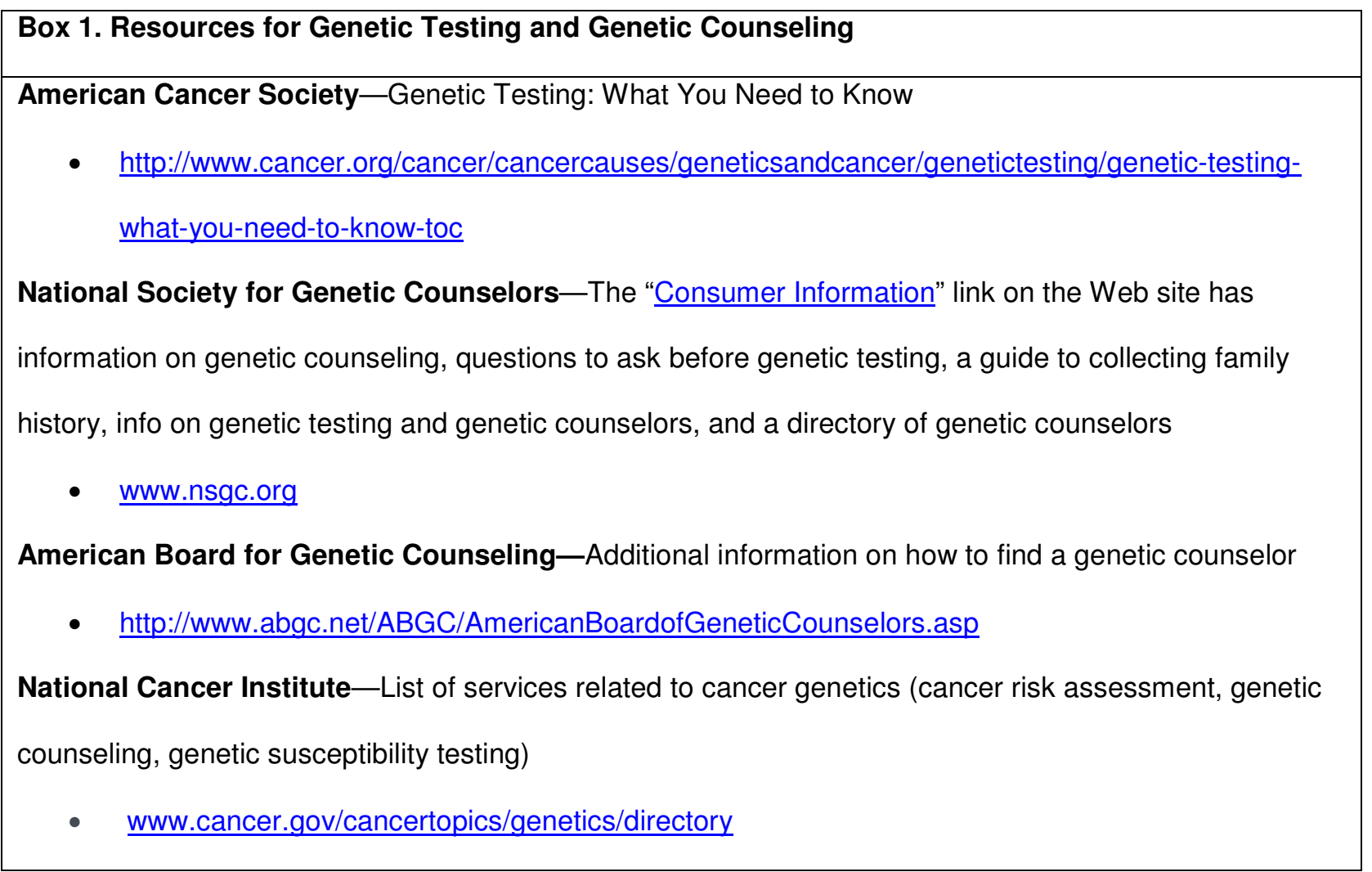




\begin{tabular}{|l|}
\hline List 2. Summary of Recommendations for Primary Prevention for Breast Cancer \\
\hline Factors that are associated with an increased risk of breast cancer: \\
- $\quad$ Obesity (weight gain important, weight loss less clear) \\
- $\quad$ Tobacco (current and previous use) \\
Factors that are associated with a decreased risk of breast cancer: \\
- Physical Activity (moderate to high levels) \\
- Chemoprevention with SERMS (recommended for women age 35 or older at high risk for breast \\
Factors that are associated with an unknown relation to risk of breast cancer: \\
- Dietary Content (fruits, vegetables, total fat, vitamins A, C, E, beta-carotene, antioxidants, \\
carbohydrates, dairy soy)
\end{tabular}

From Refs. (27-62) 


\begin{tabular}{|c|c|c|c|c|c|c|c|}
\hline \multicolumn{8}{|l|}{ ancer } \\
\hline $\begin{array}{l}\text { Screen- } \\
\text { ing } \\
\text { modality }\end{array}$ & $\begin{array}{l}\text { United } \\
\text { States } \\
\text { Preventa- } \\
\text { tive } \\
\text { Services } \\
\text { Task } \\
\text { Force }\end{array}$ & $\begin{array}{l}\text { Canadian } \\
\text { Task } \\
\text { Force on } \\
\text { the } \\
\text { Periodic } \\
\text { Health } \\
\text { Examina- } \\
\text { tion }\end{array}$ & $\begin{array}{l}\text { American } \\
\text { Cancer } \\
\text { Society }\end{array}$ & $\begin{array}{l}\text { National } \\
\text { Compre- } \\
\text { hensive } \\
\text { Cancer } \\
\text { Network }^{\mathrm{a}}\end{array}$ & $\begin{array}{l}\text { American } \\
\text { Academy } \\
\text { of Family } \\
\text { Physi- } \\
\text { cians }\end{array}$ & $\begin{array}{l}\text { American } \\
\text { College of } \\
\text { Obstetri- } \\
\text { cians and } \\
\text { Gynecol- } \\
\text { ogists }\end{array}$ & $\begin{array}{l}\text { American } \\
\text { College of } \\
\text { Radiology }\end{array}$ \\
\hline $\begin{array}{l}\text { Breast self } \\
\text { examina- } \\
\text { tion }\end{array}$ & $\begin{array}{l}\text { Do not } \\
\text { recom- } \\
\text { mend }\end{array}$ & $\begin{array}{l}\text { Do not } \\
\text { recom- } \\
\text { mend }\end{array}$ & $\begin{array}{l}\text { Breast } \\
\text { self- } \\
\text { awareness } \\
\text { encour- } \\
\text { aged }\end{array}$ & $\begin{array}{l}\text { Breast } \\
\text { self- } \\
\text { awareness } \\
\text { encour- } \\
\text { aged }\end{array}$ & $\begin{array}{l}\text { Do not } \\
\text { recom- } \\
\text { mend }\end{array}$ & $\begin{array}{l}\text { Breast } \\
\text { self- } \\
\text { awareness } \\
\text { encour- } \\
\text { aged }\end{array}$ & - \\
\hline $\begin{array}{l}\text { Clinical } \\
\text { breast } \\
\text { examina- } \\
\text { tion }\end{array}$ & $\begin{array}{l}\text { Insufficient } \\
\text { evidence }\end{array}$ & $\begin{array}{l}\text { Every } 1-2 \\
\text { years } \\
\text { starting at } \\
\text { age } 40\end{array}$ & $\begin{array}{l}\text { Every } 3 \\
\text { years from } \\
\text { ages } 20 \text { to } \\
39, \text { then } \\
\text { annually }\end{array}$ & $\begin{array}{l}\text { Every } 1-3 \\
\text { years from } \\
\text { ages } 20 \text { to } \\
39 \text {, then } \\
\text { annually }\end{array}$ & $\begin{array}{l}\text { Insufficient } \\
\text { evidence }\end{array}$ & $\begin{array}{l}\text { Every } 1-3 \\
\text { years from } \\
\text { ages } 20 \text { to } \\
39 \text {, then } \\
\text { annually }\end{array}$ & - \\
\hline $\begin{array}{l}\text { Mammog- } \\
\text { raphy }\end{array}$ & $\begin{array}{l}\text { Every } 2 \\
\text { years for } \\
\text { women } \\
\text { ages } 50 \text { to } \\
74\end{array}$ & $\begin{array}{l}\text { Annually } \\
\text { for women } \\
\text { ages } 50 \text { to } \\
74\end{array}$ & $\begin{array}{l}\text { Annually } \\
\text { beginning } \\
\text { at age } 40\end{array}$ & $\begin{array}{l}\text { Annually } \\
\text { beginning } \\
\text { at age } 40\end{array}$ & $\begin{array}{l}\text { Every } 2 \\
\text { years for } \\
\text { women } \\
\text { ages } 50 \text { to } \\
74\end{array}$ & $\begin{array}{l}\text { Annually } \\
\text { beginning } \\
\text { at age } 40\end{array}$ & $\begin{array}{l}\text { Annually } \\
\text { beginning } \\
\text { at age } 40\end{array}$ \\
\hline
\end{tabular}

${ }^{a}$ Referenced with permission from the NCCN Clinical Practice Guidelines in Oncology (NCCN 
Guidelines $\left.\AA^{\circledR}\right)$ for Breast Cancer Screening and Diagnosis V.2.2013. (C National Comprehensive Cancer Network, Inc 2013. All rights reserved. Accessed [November 19, 2013]. To view the most recent and complete version of the guideline, go online to www.nccn.org. NATIONAL COMPREHENSIVE CANCER NETWORK®, NCCN®, NCCN GUIDELINES®, and all other NCCN Content are trademarks owned by the National Comprehensive Cancer Network, Inc.

Data from Tria Tirona M. Breast cancer screening update. Am Fam Physician 2013; 87(4):277. 


\begin{tabular}{|c|c|c|c|c|c|}
\hline Risk Factor & $\begin{array}{l}\text { Clinical Breast } \\
\text { Examination }\end{array}$ & $\begin{array}{l}\text { Breast Self- } \\
\text { Awareness }\end{array}$ & Mammography & MRI & $\begin{array}{l}\text { Risk } \\
\text { Reduction } \\
\text { Options }\end{array}$ \\
\hline $\begin{array}{l}\text { BRCA } \\
\text { mutation } \\
\text { carrier }\end{array}$ & Every 6 mos & Yes & $\begin{array}{l}\text { Annually starting } \\
\text { at age } 25\end{array}$ & $\begin{array}{l}\text { Annually } \\
\text { starting } \\
\text { at age } \\
25\end{array}$ & $\begin{array}{l}\text { Mastectomy } \\
\text { bilateral } \\
\text { salpingo- } \\
\text { oophorectomy } \\
\text { Tamoxifen/ } \\
\text { raloxifene }\end{array}$ \\
\hline $\begin{array}{l}20 \% \text { or } \\
\text { greater } \\
\text { lifetime risk }\end{array}$ & Every 6- 2 mos & Yes & $\begin{array}{l}\text { Annually starting } \\
5-10 \text { y before } \\
\text { youngest breast } \\
\text { cancer diagnosis } \\
\text { in family }\end{array}$ & Offer & $\begin{array}{l}\text { Tamoxifen/ } \\
\text { raloxifene }\end{array}$ \\
\hline $\begin{array}{l}5 \text { yr risk } \\
1.7 \% \text { or } \\
\text { greater } \\
\text { based on } \\
\text { Modified Gail } \\
\text { Model }\end{array}$ & Every 6-12 mos & Yes & $\begin{array}{l}\text { Annually } \\
\text { beginning at age } \\
40\end{array}$ & Offer & $\begin{array}{l}\text { Tamoxifen/ } \\
\text { raloxifene }\end{array}$ \\
\hline $\begin{array}{l}\text { History of } \\
\text { thoracic } \\
\text { ionizing } \\
\text { radiation }\end{array}$ & Every 6-2 mos & Yes & $\begin{array}{l}\text { Annually } \\
\text { beginning at age } \\
25 \text { or } 8-10 \mathrm{yr} \\
\text { after radiation } \\
\text { exposure }\end{array}$ & Offer & \\
\hline
\end{tabular}




\begin{tabular}{|l|l|l|l|l|l|}
\hline Biopsy with & Every 6-12 mos & Yes & Annually & Offer & Tamoxifen/ \\
LCIS or & beginning at time & & raloxifene \\
atypical & & of diagnosis & & Mastectomy \\
hyperplasia & & & & & for LCIS \\
& & & & & (controversial) \\
\hline
\end{tabular}

Abbreviations: LCIS, lobular carcinoma in situ; MRI, magnetic resonance imaging.

Adapted from Griffin JL, Pearlman MD. Breast cancer screening in women at average risk and high risk. Obstet Gynecol 2010; 116(6):1417; with persmission. 
References

1. Centers for Disease Control and Prevention. Cancer prevention and control: cancer in women. Available from: http://www.cdc.gov/cancer/dcpc/data/women.htm. Accessed November 18, 2013. 2. United States cancer statistics: 1999-2010 incidence and mortality web-based report. Atlanta (GA): U.S. Department of Health and Human Services, Centers for Disease Control and Prevention and National Cancer Institute; 2013.

3. Cancer facts and figures 2014. Atlanta (GA): American Cancer Society; 2014.

4. Ravdin PM, Cronin KA, Howlader N, et al. The decrease in breast-cancer incidence in 2003 in the United States. N Engl J Med. 2007 Apr 19;356(16):1670-4.

5. Howlader N, Noone AM, Krapcho M, et al. SEER cancer statistics review, 1975-2010. Bethesda, MD: National Cancer Institute; April 2013.

6. Berry DA, Cronin KA, Plevritis SK, et al. Effect of screening and adjuvant therapy on mortality from breast cancer. N Engl J Med. 2005 Oct 27;353(17):1784-92.

7. DeSantis C, Siegel R, Bandi P, et al. Breast cancer statistics, 2011. CA Cancer J Clin. 2011 NovDec;61(6):409-18.

8. Virnig BA, Baxter NN, Habermann EB, et al. A matter of race: early-versus late-stage cancer diagnosis. Health Aff (Millwood). 2009 Jan-Feb;28(1):160-8.

9. Smith GL, Shih YC, Xu Y, Giordano SH, et al. Racial disparities in the use of radiotherapy after breastconserving surgery: a national medicare study. Cancer. 2010 Feb 1;116(3):734-41.

10. Ademuyiwa FO, Edge SB, Erwin DO, et al. Breast cancer racial disparities: unanswered questions. Cancer Res. 2011 Feb 1;71(3):640-4.

11. Sheppard VB, Isaacs C, Luta G, et al. Narrowing racial gaps in breast cancer chemotherapy initiation: the role of the patient-provider relationship. Breast Cancer Res Treat. 2013 May;139(1):207-16. 12. Wheeler SB, Reeder-Hayes KE, Carey LA. Disparities in breast cancer treatment and outcomes: biological, social, and health system determinants and opportunities for research. Oncologist. 2013;18(9):986-93.

13. Referenced with permission from the NCCN Clinical Practice Guidelines in Oncology (NCCN Guidelines $\left.{ }^{\circledR}\right)$ for Genetic/Familial Risk Assessment: Breast and Ovarian V.4.2013. @ National 
Comprehensive Cancer Network, Inc 2013. All rights reserved. Accessed [November 18, 2013]. To view the most recent and complete version of the guideline, go online to www.nccn.org. NATIONAL COMPREHENSIVE CANCER NETWORK®, NCCN®, NCCN GUIDELINES®, and all other NCCN Content are trademarks owned by the National Comprehensive Cancer Network, Inc.

14. Collaborative Group on Hormonal Factors in Breast Cancer. Familial breast cancer: collaborative reanalysis of individual data from 52 epidemiological studies including 58,209 women with breast cancer and 101,986 women without the disease. Lancet. 2001 Oct 27;358(9291):1389-99.

15. Collins LC, Baer HJ, Tamimi RM, et al. Magnitude and laterality of breast cancer risk according to histologic type of atypical hyperplasia: results from the nurses' health study. Cancer. 2007 Jan $15 ; 109(2): 180-7$.

16. Page DL, Kidd TE,Jr, Dupont WD,et al. Lobular neoplasia of the breast: higher risk for subsequent invasive cancer predicted by more extensive disease. Hum Pathol. 1991 Dec;22(12):1232-9.

17. Breast cancer facts and figures 2013-2014. Atlanta (GA): American Cancer Society, Inc; 2013. 18. McCormack VA, dos Santos Silva I. Breast density and parenchymal patterns as markers of breast cancer risk: a meta-analysis. Cancer Epidemiol Biomarkers Prev. 2006 Jun;15(6):1159-69.

19. Cummings SR, Tice JA, Bauer S, et al. Prevention of breast cancer in postmenopausal women: approaches to estimating and reducing risk. J Natl Cancer Inst. 2009 Mar 18;101(6):384-98.

20. Boyd NF, Guo H, Martin LJ, et al. Mammographic density and the risk and detection of breast cancer. N Engl J Med. 2007 Jan 18;356(3):227-36.

21. Harvey JA, Bovbjerg VE. Quantitative assessment of mammographic breast density: relationship with breast cancer risk. Radiology. 2004 Jan;230(1):29-41.

22. Pearlman MD, Griffin JL. Benign breast disease. Obstet Gynecol. 2010 Sep;116(3):747-58.

23. Kelsey JL, Gammon MD, John EM. Reproductive factors and breast cancer. Epidemiol Rev. 1993;15(1):36-47.

24. Collaborative Group on Hormonal Factors in Breast Cancer. Breast cancer and breastfeeding: Collaborative reanalysis of individual data from 47 epidemiological studies in 30 countries, including 50302 women with breast cancer and 96973 women without the disease. Lancet. 2002 Jul 20;360(9328):187-95. 
25. Breast Cancer Risk Assessment Tool. Available from: http://www.cancer.gov/bcrisktool/abouttool.aspx\#gail. Accessed November 18, 2013.

26. Griffin JL, Pearlman MD. Breast cancer screening in women at average risk and high risk. Obstet Gynecol. 2010 Dec;116(6):1410-21.

27. Claus EB, Risch N, Thompson WD. The calculation of breast cancer risk for women with a first degree family history of ovarian cancer. Breast Cancer Res Treat. 1993 Nov;28(2):115-20.

28. Food, nutrition, physical activity, and the prevention of cancer: a global perspective. Washington DC: AICR; 2007. Report No.: World Cancer Research Fund/American Institute for Cancer Research. 29. Eliassen $\mathrm{AH}$, Colditz GA, Rosner B, et al. Adult weight change and risk of postmenopausal breast cancer. JAMA. 2006 Jul 12;296(2):193-201.

30. Teras LR, Goodman M, Patel AV, et al. Weight loss and postmenopausal breast cancer in a prospective cohort of overweight and obese US women. Cancer Causes Control. 2011 Apr;22(4):573-9. 31. Christou NV, Lieberman M, Sampalis F, et al. Bariatric surgery reduces cancer risk in morbidly obese patients. Surg Obes Relat Dis. 2008 Nov-Dec;4(6):691-5.

32. McCawley GM, Ferriss JS, Geffel D, et al. Cancer in obese women: potential protective impact of bariatric surgery. J Am Coll Surg. 2009 Jun;208(6):1093-8.

33. Mandelblatt J, van Ravesteyn N, Schechter C, et al. Which strategies reduce breast cancer mortality most: a collaborative modeling of optimal screening, treatment, and obesity prevention. Cancer. 2013 Jul $15 ; 119(14): 2541-8.34$.

24. Peters TM, Schatzkin A, Gierach GL, et al. Physical activity and postmenopausal breast cancer risk in the NIH-AARP diet and health study. Cancer Epidemiol Biomarkers Prev. 2009 Jan;18(1):289-96.

35. Friedenreich CM, Cust AE. Physical activity and breast cancer risk: impact of timing, type and dose of activity and population subgroup effects. Br J Sports Med. 2008 Aug;42(8):636-47.

36. Steindorf K, Ritte R, Eomois PP, et al. Physical activity and risk of breast cancer overall and by hormone receptor status: the European prospective investigation into cancer and nutrition. Int $\mathrm{J}$ Cancer. 2013 Apr 1;132(7):1667-78.

37. Smith-Warner SA, Spiegelman D, Yaun SS, et al. Intake of fruits and vegetables and risk of breast cancer: a pooled analysis of cohort studies. JAMA. 2001 Feb 14;285(6):769-76. 
38. Michels KB, Mohllajee AP, Roset-Bahmanyar E, et al. Diet and breast cancer: a review of the prospective observational studies. Cancer. 2007 Jun 15;109(12 Suppl):2712-49.

39. van Gils $\mathrm{CH}$, Peeters $\mathrm{PH}$, Bueno-de-Mesquita $\mathrm{HB}$, et al. Consumption of vegetables and fruits and risk of breast cancer. JAMA. 2005 Jan 12;293(2):183-93.

40. Ferrari $\mathrm{P}$, Rinaldi S, Jenab M, et al. Dietary fiber intake and risk of hormonal receptor-defined breast cancer in the European prospective investigation into cancer and nutrition study. Am J Clin Nutr. 2013 Feb;97(2):344-53.

41. Luo J, Margolis KL, Wactawski-Wende J, et al. Association of active and passive smoking with risk of breast cancer among postmenopausal women: a prospective cohort study. BMJ. 2011 Mar 1;342:d1016. 42. Saquib N, Stefanick ML, Natarajan L, Pierce JP. Mortality risk in former smokers with breast cancer: pack-years vs. smoking status. Int J Cancer. 2013 May 3.

43. Key J, Hodgson S, Omar RZ, et al. Meta-analysis of studies of alcohol and breast cancer with consideration of the methodological issues. Cancer Causes Control. 2006 Aug;17(6):759-70.

44. Baan R, Straif K, Grosse Y, Secretan B, et al. Carcinogenicity of alcoholic beverages. Lancet Oncol. 2007 Apr;8(4):292-3.

45. Smith-Warner SA, Spiegelman D, Yaun SS, et al. Alcohol and breast cancer in women: a pooled analysis of cohort studies. JAMA. 1998 Feb 18;279(7):535-40.

46. Allen NE, Beral V, Casabonne D, et al. Moderate alcohol intake and cancer incidence in women. J Natl Cancer Inst. 2009 Mar 4;101(5):296-305.

47. Dorgan JF, Baer DJ, Albert PS, et al. Serum hormones and the alcohol-breast cancer association in postmenopausal women. J Natl Cancer Inst. 2001 May 2;93(9):710-5.

48. Rinaldi S, Peeters PH, Bezemer ID, et al. Relationship of alcohol intake and sex steroid concentrations in blood in pre- and post-menopausal women: the European prospective investigation into cancer and nutrition. Cancer Causes Control. 2006 Oct;17(8):1033-43.

49. Hamajima N, Hirose $\mathrm{K}$, Tajima K, et al. Alcohol, tobacco and breast cancer--collaborative reanalysis of individual data from 53 epidemiological studies, including 58515 women with breast cancer and 95 067 women without the disease. Br J Cancer. 2002 Nov 18;87(11):1234-45. 
50. Tjonneland A, Christensen J, Olsen A, et al. Alcohol intake and breast cancer risk: the European prospective investigation into cancer and nutrition (EPIC). Cancer Causes Control. 2007 May;18(4):36173.

51. Terry MB, Zhang FF, Kabat G, et al. Lifetime alcohol intake and breast cancer risk. Ann Epidemiol. 2006 Mar;16(3):230-40.

52. Fisher B, Costantino JP, Wickerham DL, et al. Tamoxifen for prevention of breast cancer: report of the national surgical adjuvant breast and bowel project P-1 study. J Natl Cancer Inst. 1998 Sep $16 ; 90(18): 1371-88$.

53. Fisher B, Costantino JP, Wickerham DL et al. Tamoxifen for the prevention of breast cancer: current status of the national surgical adjuvant breast and bowel project P-1 study. J Natl Cancer Inst. 2005 Nov 16;97(22):1652-62.

54. Cuzick J, Sestak I, Bonanni B, et al. Selective oestrogen receptor modulators in prevention of breast cancer: an updated meta-analysis of individual participant data. The Lancet. 2013 5/25$31 ; 381(9880): 1827-34$.

55. Cuzick J, Forbes JF, Sestak I, et al. Long-term results of tamoxifen prophylaxis for breast cancer--96month follow-up of the randomized IBIS-I trial. J Natl Cancer Inst. 2007 Feb 21;99(4):272-82.

56. Veronesi U, Maisonneuve P, Rotmensz N, et al. Tamoxifen for the prevention of breast cancer: late results of the Italian randomized tamoxifen prevention trial among women with hysterectomy. J Natl Cancer Inst. 2007 May 2;99(9):727-37.

57. Powles TJ, Ashley S, Tidy A, et al. Twenty-year follow-up of the Royal Marsden randomized, doubleblinded tamoxifen breast cancer prevention trial. J Natl Cancer Inst. 2007 Feb 21;99(4):283-90.

58. Cuzick J, Powles T, Veronesi U, et al. Overview of the main outcomes in breast-cancer prevention trials. Lancet. 2003 Jan 25;361(9354):296-300.

59. Cummings SR, Eckert S, Krueger KA, et al. The effect of raloxifene on risk of breast cancer in postmenopausal women: results from the MORE randomized trial. JAMA. 1999 Jun 16;281(23):2189-97. 60. Vogel VG, Costantino JP, Wickerham DL, et al. Update of the national surgical adjuvant breast and bowel project study of tamoxifen and raloxifene (STAR) P-2 trial: preventing breast cancer. Cancer Prev Res (Phila). 2010 Jun;3(6):696-706. 
61. Martino S, Cauley JA, Barrett-Connor E, et al. Continuing outcomes relevant to evista: breast cancer incidence in postmenopausal osteoporotic women in a randomized trial of raloxifene. J Natl Cancer Inst. 2004 Dec 1;96(23):1751-61.

62. Barrett-Connor E, Mosca L, Collins P, et al. Effects of raloxifene on cardiovascular events and breast cancer in postmenopausal women. N Engl J Med. 2006 Jul 13;355(2):125-37.

63. Referenced with permission from the NCCN Clinical Practice Guidelines in Oncology (NCCN Guidelines ${ }^{\circledR}$ ) for Breast Cancer Risk Reduction V.1.2013. @ National Comprehensive Cancer Network, Inc 2013. All rights reserved. Accessed [November 18, 2013]. To view the most recent and complete version of the guideline, go online to www.nccn.org. NATIONAL COMPREHENSIVE CANCER NETWORK®, NCCN®, NCCN GUIDELINES $\AA$, and all other NCCN Content are trademarks owned by the National Comprehensive Cancer Network, Inc.

64. Moss SM, Cuckle H, Evans A, et al. Effect of mammographic screening from age 40 years on breast cancer mortality at 10 years' follow-up: a randomised controlled trial. Lancet. 2006 Dec 9;368(9552):205360.

65. Bjurstam N, Bjorneld L, Warwick J, et al. The Gothenburg breast screening trial. Cancer. 2003 May 15;97(10):2387-96 .

66. Gotzsche PC, Jorgensen KJ. Screening for breast cancer with mammography. Cochrane Database Syst Rev. 2013 Jun 4;6:CD001877.

67. Nelson HD, Tyne K, Naik A, et al. Screening for breast cancer: an update for the U.S. preventive services task force. Ann Intern Med. 2009 Nov 17;151(10):727,37, W237-42.

68. Tonelli M, Connor Gorber S, Joffres M, et al.Canadian Task Force on Preventive Health Care, Recommendations on screening for breast cancer in average-risk women aged 40-74 years. CMAJ. 2011 Nov 22;183(17):1991-2001.

69. American College of Obstetricians-Gynecologists. Practice bulletin no. 122: breast cancer screening. Obstet Gynecol. 2011 Aug;118(2 Pt 1):372-82.

70. Smith RA, Brooks D, Cokkinides V, et al. Cancer screening in the United States, 2013. CA: A Cancer Journal for Clinicians. 2013;63(2):87-105. 
71. Referenced with permission from the NCCN Clinical Practice Guidelines in Oncology (NCCN Guidelines ${ }^{\circledR}$ ) for Breast Cancer Screening and Diagnosis V.2.2013. ( ) National Comprehensive Cancer Network, Inc 2013. All rights reserved. Accessed [November 19, 2013]. To view the most recent and complete version of the guideline, go online to www.nccn.org. NATIONAL COMPREHENSIVE CANCER NETWORK®, NCCN®, NCCN GUIDELINES®, and all other NCCN Content are trademarks owned by the National Comprehensive Cancer Network, Inc.

72. Webb ML, Cady B, Michaelson JS, et al. A failure analysis of invasive breast cancer: most deaths from disease occur in women not regularly screened. Cancer. 2013 Sep 9.

73. Independent UK Panel on Breast Cancer Screening. The benefits and harms of breast cancer screening: an independent review. Lancet. 2012 Nov 17;380(9855):1778-86.

74. Andersson I, Aspegren K, Janzon L, et al. Mammographic screening and mortality from breast cancer: the malmo mammographic screening trial. BMJ. 1988 Oct 15;297(6654):943-8.

75. Frisell J, Lidbrink E, Hellstrom L, et al. Followup after 11 years--update of mortality results in the Stockholm mammographic screening trial. Breast Cancer Res Treat. 1997 Sep;45(3):263-70.

76. Miller AB, To T, Baines CJ, Wall C. Canadian national breast screening study-2: 13-year results of a randomized trial in women aged 50-59 years. J Natl Cancer Inst. 2000 Sep 20;92(18):1490-9.

77. Nystrom L, Andersson I, Bjurstam N, et al. Long-term effects of mammography screening: an updated review of the Swedish randomised trials. Lancet 2002; 359(9310):909-19.

78. Shapiro S. Periodic screening for breast cancer: the HIP (health insurance plan) randomized controlled trial. J Natl Cancer Inst Monogr. 1997;(22)(22):27-30.

79.. Tabar L, Vitak B, Chen HH, et al. The Swedish two-county trial twenty years later: updated mortality results and new insights from long-term follow-up. Radiol Clin North Am. 2000 Jul;38(4):625-51. 80. Mandelblatt JS, Cronin KA, Bailey S, et al. Effects of mammography screening under different screening schedules: model estimates of potential benefits and harms. Ann Intern Med. 2009 Nov $17 ; 151(10): 738-47$.

81. Kolb TM, Lichy J, Newhouse JH. Comparison of the performance of screening mammography, physical examination, and breast US and evaluation of factors that influence them: an analysis of 27,825 patient evaluations. Radiology. 2002 Oct;225(1):165-75. 
82. Berg WA, Blume JD, Cormack JB, et al. Combined screening with ultrasound and mammography vs mammography alone in women at elevated risk of breast cancer. JAMA. 2008 May 14;299(18):2151-63. 83. 16-year mortality from breast cancer in the UK trial of early detection of breast cancer. Lancet. 1999 Jun 5;353(9168):1909-14.

84. Semiglazov VF, Manikhas AG, Moiseenko VM, et al. Results of a prospective randomized investigation [Russia (st.Petersburg)/WHO] to evaluate the significance of self-examination for the early detection of breast cancer. Vopr Onkol. 2003;49(4):434-41.

85. Thomas DB, Gao DL, Ray RM, et al. Randomized trial of breast self-examination in Shanghai: final results. J Natl Cancer Inst. 2002 Oct 2;94(19):1445-57.

86. Kosters JP, Gotzsche PC. Regular self-examination or clinical examination for early detection of breast cancer. Cochrane Database Syst Rev. 2003;(2)(2):CD003373.

87. Hackshaw AK, Paul EA. Breast self-examination and death from breast cancer: a meta-analysis. Br J Cancer. 2003 Apr 7;88(7):1047-53.

88. Tu SP, Reisch LM, Taplin SH, et al. Breast self-examination: self-reported frequency, quality, and associated outcomes. J Cancer Educ. 2006 Fall;21(3):175-81.

89. Lalkhen AG, McCluskey A. Clinical tests: sensitivity and specificity. Continuing Education in Anaesthesia, Critical Care \& Pain. 2008 December 01;8(6):221-3.

90. Bobo JK, Lee NC, Thames SF. Findings from 752081 clinical breast examinations reported to a national screening program from 1995 through 1998. J Natl Cancer Inst. 2000 Jun 21;92(12):971-6. 91. Bancej C, Decker K, Chiarelli A, et al. Contribution of clinical breast examination to mammography screening in the early detection of breast cancer. J Med Screen. 2003;10(1):16-21.

92. Kerlikowske K, Grady D, Rubin SM, et al. Efficacy of screening mammography: a meta-analysis. JAMA. 1995 Jan 11;273(2):149-54.

93. Humphrey LL, Helfand M, Chan BK,et al. Breast cancer screening: a summary of the evidence for the U.S. preventive services task force. Ann Intern Med. 2002 Sep 3;137(5 Part 1):347-60.

94. Saslow D, Hannan J, Osuch J, et al. Clinical breast examination: practical recommendations for optimizing performance and reporting. CA Cancer J Clin. 2004 Nov-Dec;54(6):327-44. 
95. Saslow D, Boetes C, Burke W, et al. American Cancer Society guidelines for breast screening with MRI as an adjunct to mammography. CA Cancer Journal for Clinicians. 2007;57(2):75-89.

96. Warner $\mathrm{E}$, Messersmith $\mathrm{H}$, Causer $\mathrm{P}$, et al. Systematic review: using magnetic resonance imaging to screen women at high risk for breast cancer. Ann Intern Med. 2008 May 6;148(9):671-9.

97. Kriege M, Brekelmans CTM, Boetes C, et al. Efficacy of MRI and mammography for breast-cancer screening in women with a familial or genetic predisposition. N Engl J Med. 2004 07/29; 2013/08;351(5):427-37.

98. Kuhl CK, Schrading S, Leutner CC, et al. Mammography, breast ultrasound, and magnetic resonance imaging for surveillance of women at high familial risk for breast cancer. J Clin Oncol. 2005 Nov 20;23(33):8469-76.

99. Leach MO, Boggis CR, Dixon AK, et al. Screening with magnetic resonance imaging and mammography of a UK population at high familial risk of breast cancer: a prospective multicentre cohort study (MARIBS). Lancet. 2005 May 21-27;365(9473):1769-78.

100. Kriege M, Brekelmans CT, Boetes C, et al. Differences between first and subsequent rounds of the MRISC breast cancer screening program for women with a familial or genetic predisposition. Cancer. 2006 Jun 1;106(11):2318-26.

101. Warner E, Plewes DB, Hill KA, et al. Surveillance of BRCA1 and BRCA2 mutation carriers with magnetic resonance imaging, ultrasound, mammography, and clinical breast examination. JAMA. 2004 Sep 15;292(11):1317-25.

102. Sardanelli F, Podo F, Santoro F, et al. Multicenter surveillance of women at high genetic breast cancer risk using mammography, ultrasonography, and contrast-enhanced magnetic resonance imaging (the high breast cancer risk Italian 1 study): final results. Invest Radiol. 2011 Feb;46(2):94-105.

103. Le-Petross HT, Whitman GJ, Atchley DP, et al. Effectiveness of alternating mammography and magnetic resonance imaging for screening women with deleterious BRCA mutations at high risk of breast cancer. Cancer. 2011 Sep 1;117(17):3900-7.

104. Pace LE, He Y, Keating NL. Trends in mammography screening rates after publication of the 2009 US preventive services task force recommendations. Cancer. 2013;119(14):2518-23. 
105. Howard DH, Adams EK. Mammography rates after the 2009 US preventive services task force breast cancer screening recommendation. Prev Med. 2012 Nov;55(5):485-7.

106. Yasmeen S, Romano PS, Tancredi DJ, et al. Screening mammography beliefs and recommendations: a web-based survey of primary care physicians. BMC Health Serv Res. 2012 Feb 6;12:32,6963-12-32.

107. Meissner HI, Klabunde CN, Han PK,et al. Breast cancer screening beliefs, recommendations and practices: primary care physicians in the United States. Cancer. 2011 Jul 15;117(14):3101-11.

108. Centers for Disease Control and Prevention (CDC). Cancer screening - United States, 2010. MMWR Morb Mortal Wkly Rep. 2012 Jan 27;61(3):41-5.

109. Older americans 2012: key indicators of wellbeing. Available from:

http://www.agingstats.gov/agingstatsdotnet/Main Site/Data/2012 Documents/Docs/EntireChartbook.pdf. Accessed November 18, 2013.

110. Schueler KM, Chu PW, Smith-Bindman R. Factors associated with mammography utilization: a systematic quantitative review of the literature. J Womens Health (Larchmt). 2008 Nov;17(9):1477-98. 111. SJ Curry, T Byers, M Hewitt, editor. Fulfilling the potential for cancer prevention and early detection. Washington DC: National Academies Press; 2003.

112. Watson-Johnson LC, DeGroff A, Steele CB, et al. Mammography adherence: a qualitative study. J Womens Health (Larchmt). 2011 Dec;20(12):1887-94.

113. Meissner HI, Klabunde CN, Breen N, Zapka JM. Breast and colorectal cancer screening: U.S. primary care physicians' reports of barriers. Am J Prev Med. 2012 Dec;43(6):584-9.

114. Taplin SH, Ichikawa L, Yood MU, et al. Reason for late-stage breast cancer: absence of screening or detection, or breakdown in follow-up? Journal of the National Cancer Institute. 2004 October 20;96(20):1518-27.

115. Zapka J, Taplin SH, Price RA, et al. Factors in quality care--the case of follow-up to abnormal cancer screening tests--problems in the steps and interfaces of care. J Natl Cancer Inst Monogr. 2010;2010(40):58-71.

116. Campbell RT, Li X, Dolecek TA, Barrett RE, et al. Economic, racial and ethnic disparities in breast cancer in the US: towards a more comprehensive model. Health Place. 2009 Sep;15(3):855-64. 
117. Silber JH, Rosenbaum PR, Clark AS, et al. Characteristics associated with differences in survival among black and white women with breast cancer. JAMA. 2013 Jul 24;310(4):389-97.

118. Levy AR, Bruen BK, Ku L. Health care reform and women's insurance coverage for breast and cervical cancer screening. Prev Chronic Dis. 2012 Oct;9:E159.

119. Sarfaty M, Wender R, Smith R. Promoting cancer screening within the patient centered medical home. CA Cancer J Clin. 2011 Nov-Dec;61(6):397-408.

120. Peek ME, Han JH. Disparities in screening mammography: current status, interventions and implications. J Gen Intern Med. 2004 Feb;19(2):184-94.

121. Plescia M, Richardson LC, Joseph D. New roles for public health in cancer screening. CA Cancer J Clin. 2012 Jul-Aug;62(4):217-9.

122. Kern LM, Barron Y, Dhopeshwarkar RV, et al. Electronic health records and ambulatory quality of care. J Gen Intern Med. 2013 Apr;28(4):496-503. 